\title{
Aplikasi Portofolio Dosen Untuk Pengelolaan Data Kegiatan Tridharma Perguruan Tinggi
}

\author{
Mira Ziveria'), Muhammad Rusli ${ }^{2}$ \\ Program Studi Sistem Informasi Institut Teknologi dan Bisnis KALBIS \\ Jalan Pulomas Selatan Kav.22 Jakarta Timur 13210 \\ Email:mira.ziveria@kalbis.ac.id \\ Email: Muhammad.rusli@kalbis.ac.id
}

\begin{abstract}
The main task of the lecturer is to implement the tridharma of higher education. In order to carry out the duties of the lecturer in accordance with the rules and regulations, an evaluation is needed. Evaluation is carried out in the form of assessment and measurement of lecturer performance in a certain period of time. Performance evaluation can be seen from several processes such as the assessment of Lecturers' Functional and Academic Position, Lecturer Certification, Lecturer Workload, and others. All lecturer performance evaluations require portfolio data that contains the activities of the higher education tridharma carried out by the lecturer for a certain period of time. This study aims to build the application of lecturer portfolios for data management of tridharma activities of higher education using the System Development Life Cycle (SDLC), system design using UML, data storage in MySQL and programming with PHP. The results of the study are an application of the lecturer portfolio which is expected to facilitate lecturers and universities to manage data on tridharma activities that have been carried out by the lecturer for a certain period of time.
\end{abstract}

Keywords: $M y S Q L$, portfolio, SDLC, tridharma, UML

\begin{abstract}
Abstrak: Tugas utama dosen adalah melaksanakan tridharma perguruan tinggi. Supaya pelaksanaan tugas dosen berjalan sesuai dengan peraturan dan undang-undang maka diperlukan evaluasi. Evaluasi dilakukan dalam bentuk penilaian dan pengukuran kinerja dosen dalam periode waktu tertentu. Evaluasi kinerja dapat dilihat dari beberapa proses seperti penilaian Jabatan Fungsional dan Akademik Dosen, Sertifikasi Dosen, Beban Kerja Dosen, dan lain-lain. Semua evaluasi kinerja dosen membutuhkan data portofolio yang memuat kegiatan tridharma perguruan tinggi yang dilaksanakan oleh dosen dalam periode waktu tertentu. Penelitian ini bertujuan untuk membangun aplikasi portofolio dosen untuk pengelolaan data kegiatan tridharma perguruan tinggi menggunakan System Development Life Cycle (SDLC), perancangan sistem menggunakan UML, penyimpanan data pada MySQL dan pemrograman dengan PHP. Hasil penelitian adalah sebuah aplikasi portofolio dosen yang diharapkan dapat memudahkan dosen maupun perguruan tinggi mengelola data kegiatan tridharma yang telah dilaksanakan oleh dosen pada periode waktu tertentu.
\end{abstract}

Kata kunci: MySQL, portofolio, SDLC, tridharma perguruan tinggi, UML

\section{PENDAHULUAN}

Pendidikan Tinggi adalah jenjang pendidikan setelah pendidikan menengah yang mencakup program diploma, program sarjana, program magister, program doktor, dan program profesi, serta program spesialis, yang diselenggarakan oleh perguruan tinggi berdasarkan kebudayaan Bangsa Indonesia. Tridharma Perguruan Tinggi yang selanjutnya disebut Tridharma adalah kewajiban Perguruan Tinggi untuk menyelenggarakan Pendidikan, penelitian, dan pengabdian kepada masyarakat. Tugas utama dosen adalah melaksanakan Tridharma Perguruan Tinggi dengan beban kerja paling sedikit sepadan dengan 12 (dua belas) SKS dan paling banyak 16 (enam belas) SKS pada setiap semester sesuai dengan kualifikasi akademik. Kompetensi dosen menentukan kualitas pelaksanaan Tridharma Perguruan Tinggi sebagaimana yang ditunjukkan dalam kegiatan profesional dosen. Untuk menjamin pelaksanaan tugas dosen berjalan sesuai dengan kriteria yang ditetapkan dalam peraturan perundang undangan maka perlu dievaluasi setiap periode waktu yang ditentukan.

Evaluasi dosen dalam menjalankan tri dharma perguruan tinggi diperlukan untuk meningkatkan 
profesionalisme dosen dalam melaksanakan tugas, meningkatkan proses dan hasil pendidikan, menilai akuntabilitas kinerja dosen di perguruan tinggi, meningkatkan atmosfer akademik di semua jenjang perguruan tinggi dan mempercepat terwujudnya tujuan pendidikan nasional. Penilaian dan pengukuran kinerja dosen dapat dilihat dari beberapa proses seperti penilaian Jabatan Fungsional dan Akademik Dosen, Sertifikasi Dosen, Beban Kerja Dosen, dan lain-lain. Untuk menyusun pengajuan penilaian dosen untuk penunjang tri dharma perguruan tinggi dibutuhkan data portofolio atau data riwayat hidup dosen atau curriculum vitae dengan format yang tidak sama. Untuk memudahkan dosen menyusun daftar riwayat hidup tersebut yang sesuai dengan format yang dibutuhkan untuk masing-masing penilaian maka penelitian ini mengusulkan untuk membuat aplikasi riwayat hidup dosen untuk penunjang tri dharma perguruan tinggi. [1]

Berdasarkan uraian latar belakang permasalahan tersebut, maka perumusan masalah pada penelitian ini adalah bagaimana membangun sebuah aplikasi portofolio dosen yang dapat digunakan untuk pengelolan data kegiatan tridharma perguruan tinggi? Dalam penelitianini adabeberapa pembatasan masalah yang dilakukan adalah bahwa aplikasi dirancang berdasarkan data kegiatan tridharma perguruan tinggi yang dilakukan oleh dosen sesuai mekanisme atau format pengajuan dan penilaian dosen untuk Jabatan Fungsional dan Akademik Dosen, Sertifikasi Dosen, dan Beban Kerja Dosen.

Tujuan penelitian ini adalah untuk membangun aplikasi portofolio dosen untuk pengelolaan data kegiatan tridharma perguruan tinggi. Penelitian ini dapat memberikan manfaat terutama untuk dosen yaitu memudahkan dosen mengelola data kegiatan tridharma perguruan tinggi yang pernah dilaksanakan dan memudahkan dosen menyusun portofolio untuk penilaian Jabatan Fungsional dan Akademik Dosen, Sertifikasi Dosen, Beban Kerja Dosen, serta kebutuhan lainnya. Bagi perguruan tinggi adalah memudahkan perguruan tinggi mengelola data tridharma yang dilaksanakan oleh dosen-dosennya, memudahkan mengevaluasi kinerja dosen dalam melaksanakan kegiatan tridharma, serta memudahkan menyusun portofolio jurusan atau program studi untuk kepentingan akreditasi.

Komponen penilaian dalam jabatan akademik dosen terdiri dari (i) unsur utama yang meliputi: pendidikan (meliputi pendidikan sekolah dan pelaksanaan pendidikan (pengajaran), penelitian (meliputi pelaksanaan penelitian dan menghasilkan karya ilmiah sains/teknologi/seni/sastra), dan pengabdian kepada masyarakat dan (ii) unsur penunjang yang merupakan kegiatan pendukung pelaksanaan tugas pokok dosen. Jumlah angka kredit kumulatif minimal yang harus dipenuhi oleh setiap dosen untuk dapat diangkat dalam jabatan akademik paling sedikit dibutuhkan angka kredit 90\% (sembilan puluh persen) dari unsur utama tidak termasuk pendidikan sekolah yang memperoleh ijazah/gelar dan Pendidikan dan Pelatihan (Diklat) Prajabatan. [2]

Sertifikasi dosen (Serdos) adalah proses pemberian sertifikat pendidik kepada dosen. Program ini merupakan upaya meningkatkan mutu pendidikan nasional, dan memperbaiki kesejahteraan dosen, dengan mendorong dosen untuk secara berkelanjutan meningkatkan profesionalismenya. Sebagai bahan acuan pembuatan narasi deskripsi diri, Dosen Yang Disertifikasi (DYS) harus menyusun Curicullum Vitae (CV) yang terdiri atas riwayat pendidikan, riwayat pengajaran, riwayat pelatihan profesional, produk bahan ajar, riwayat penelitian, riwayat pengabdian, riwayat dan publikasi karya ilmiah, pertemuan ilmiah, peran di bidang kemahasiswaan, dan tanda prestasi/penghargaan. [3]

Template pengisian portofolio untuk pengajuan jabatan fungsional dosen berdasarkan Lampiran I Format F1 Laporan Beban Kerja Dosen Semester II Tahun 20017/2008. [3]. UML yaitu bahasa spesifikasi standar digunakan untuk mendokumentasikan, menspesifikasikan, dan membangun sistem perangkat lunak. UML merupakan sebuah tool untuk merancang pembuatan software atau aplikasi yang berorientasi objek misalnya java dan yang lainnya dalam bentuk diagram. Diagram UML diantaranya adalah Use Case Diagram, Activity Diagram, Class Diagram. [4]

SDLC adalah metode pengembangan sistem yang dijadikan landasan para pengembang untuk melakukan pengembangan aplikasi agar aplikasi yang dihasilkan sesuai dengan kebutuhan dan proses bisnis. Metode pengembangan sistem yang digunakan adalah Software Development Life Cycle (SDLC) dengan model waterfall. Metode SDLC waterfall sering juga disebut model sekuensial linier (sequential linear) atau alur hidup klasik (classic life cycle) yang dimulai dari analisis, desain, pengodean, pengujian dan tahap pendukung. [5]

\section{METODE PENELITIAN}

\section{A. Studi Pendahuluan}

Studi pendahuluan dalam penelitian ini meliputi observasi awal, studi literatur, perumusan masalah, 
penentuan tujuan dan lingkup penelitian. Observasi merupakan tahap awal dari penelitian. Observasi dilakukan dalam waktu Januari 2017 sampai dengan Januari 2018. Tahap ini dilakukan untuk mengetahui pengeloaan kegiatan tridharma yang dilakukan oleh dosen di perguruan tinggi. Dalam tahap ini juga mengamati data-data yang digunakan oleh dosen untuk menyusun portofolio untuk beberapa kebutuhan, seperti pengajuan sertifikasi dosen, pengurusan jenjang kepangkatan atau jabatan fungsional dosen, pelaporan beban kerja dosen, dan kebutuhan lainnya. Pada tahap studi literatur dikumpulkan berbagai referensi dan teori-teori yang berkaitan dengan permasalahan yang ada sebagai landasan dalam tahap-tahap penelitian selanjutnya. Dari referensi dan teori-teori tersebut kemudian dibuat skema pemikiran untuk mengetahui Gambaran besar dari rancangan yang diinginkan.

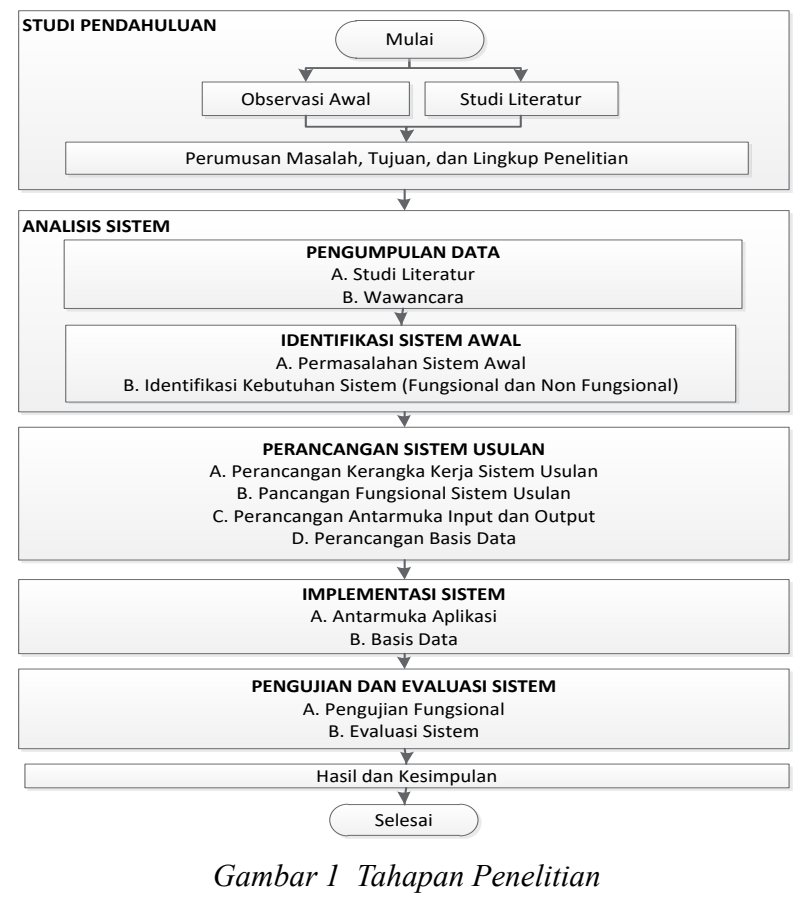

Dari Gambar 1, hasil observasi awal dan studi literatur dapat diidentifikasi masalah bahwa proses pengelolaan data kegiatan tridharma perguruan tinggi yang dilakukan oleh dosen seringkali mengalami kendala dimana dosen pada saat melakukan pengajuan atau pelaporan kinerjanya, baik di lingkungan institusi atau perguruan tingginya bernaung, maupun diluar lingkungan institusinya dengan mekanisme dan format yang tidak sama. Portofolio dibutuhkan oleh dosen antara lain untuk pengajuan dan kenaikan jabatan akademik dan fungsional, pengajuan sertifikasi dosen, pelaporan beban kerja dosen, pengajuan akreditasi jurusan, pengajuan untuk pengukuran pencapaian kinerja di lingkungan institusi, pengajuan proposal penelitian, proposal pengabdian kepada masyarakat, dan lainlain sebagainya.

\section{B. Analisis Sistem}

Analisis Sistem bertujuan untuk menganalisis sistem yang berjalan sekarang untuk pengelolaan data kegiatan tridharma yang dilakukan oleh dosen serta menganalisis kebutuhan data untuk pembuatan portofolio dosen untuk berbagai kebutuhan. Pengumpulan data dilakukan melalui studi pustaka dan wawancara kepada beberapa dosen dan juga beberapa pejabat struktural yang selalu berkaitan dengan pengelolaan data portofolio dosen pada Institut Teknologi dan Bisnis Kalbis, seperti ketua jurusan, sekretaris jurusan, biro dukungan kerjasama dan akademik dosen, biro penelitian, publikasi dan pengabdian kepada masyarakat. Dari permasalahan sistem diatas akan digunakan untuk mengidentifikasi kebutuhan sistem untuk pembangunan aplikasi portofolio dosen yang meliputi kebutuhan fungsional dan non fungsional sistem yang diusulkan.

\section{Perancangan Sistem Usulan}

Pada tahap perancangan sistem ini didahului dengan pembuatan rancangan kerangka kerja sistem usulan yang dibuat berdasarkan hasil analisis sistem awal. Pembuatan rancangan kerangka kerja sistem usulan ini terdiri dari pembuatan bagan kerangka kerja usulan berbentuk flowchart. Perancangan fungsional sistem menggunakan UML yang meliputi use case diagram, activity diagram, class diagram, perancangan antarmuka input dan output, dan perancangan basis data secara konseptual, lojikal, dan fisikal yang dilakukan.

\section{Implementasi Sistem}

Implementasi sistem meliputi implementasi antarmuka aplikasi yang merupakan penulisan kode program sesuai antar muka dan sistem yang telah dirancang, serta implementasi basis data yang akan digunakan untuk aplikasi.

\section{E. Pengujian dan Evaluasi Sistem}

Pengujian dan evaluasi dilakukan untuk mengetahui apakah program yang dibuat telah sesuai dengan kebutuhan sistem atau belum. Metode pengujian yang digunakan adalah pengujian black box yaitu pengujian yang berfokus pada kebutuhan fungsional dari aplikasi berdasarkan spesifikasi kebutuhan fungsional sistem yang sudah ditetapkan sebelumnya. Hasil pengujian digunakan untuk mengevaluasi sistem yang telah dibangun. 


\section{F. Tempat dan Waktu Penelitian}

Kegiatan penelitian ini dilakukan di Bagian Pengembangan Akademik lantai 2 Kampus Kalbis Institute yang berada di Jl. Pulomas Selatan Kav. 22 Jakarta Timur. Penelitian ini dilakukan selama satu tahun yaitu dimulai bulan Januari 2018 sampai dengan Januari 2019.

\section{HASIL DAN PEMBAHASAN}

Pada bagian ini akan dijelaskan mengenai hasil analisis dan pembahasan aplikasi riwayat hidup bagi dosen sebagai penunjang tridharma perguruan tinggi meliputi tahapan analisis, perancangan, implementasi, serta pengujian dan evaluasi sistem.

\section{A. Analisis Sistem}

Analisis sistem bertujuan untuk menganalisis sistem yang berjalan sekarang untuk pengelolaan data kegiatan tridharma yang dilakukan oleh dosen serta menganalisis kebutuhan data untuk pembuatan portofolio dosen untuk berbagai kebutuhan.

\section{Pengumpulan Data}

Pengumpulan data dilakukan melalui studi pustaka dan wawancara kepada beberapa dosen dan juga beberapa pejabat struktural yang selalu berkaitan dengan pengelolaan data portofolio dosen pada Institut Teknologi dan Bisnis Kalbis, seperti ketua jurusan, sekretaris jurusan, biro dukungan kerjasama dan akademik dosen, biro penelitian, publikasi dan pengabdian kepada masyarakat. Dari permasalahan sistem diatas akan digunakan untuk mengidentifikasi kebutuhan sistem untuk pembangunan aplikasi portofolio dosen yang meliputi kebutuhan fungsional dan non fungsional sistem yang diusulkan.

Data yang diperlukan dalam penelitian ini adalah dokumen apa saja yang menjadi komponen penyusunan pengajuan atau kenaikan jabatan fungsional dan akademik, sertifikasi dosen, dan pelaporan untuk evaluasi beban kerja dosen. Dari data yang ada kemudian dilakukan analisis untuk mengetahui kebutuhan sistem yang nantinya akan digunakan sebagai acuan dalam pengembangan sistem yang baru.

\section{Identifikasi Sistem Awal}

Identifikasi sistem awal dilakukan melalui studi pustaka dan wawancara kepada pihak yang berwenang, yaitu Ibu Satya Candrasari, S. Sos., M.Ikom. selaku Kepala Biro Dukungan Kerjasama dan Akademik Dosen, Ibu Ridha Sefina Samosir,
S.Si., M.Kom. selaku ketua jurusan Sistem Informasi Institut Teknologi dan Bisnis Kalbis, serta beberapa dosen seperti Bapak Drs. Muhammad Rusli, M.M. selaku dosen pada jurusan Sistem Informasi Institut Teknologi dan Bisnis Kalbis, Bapak Salman, S.E., M.Ikom selaku dosen jurusan Ilmu Komunikasi Institut Teknologi dan Bisnis Kalbis, dan lainlain. Beberapa informasi yang diperoleh dari hasil wawancara antara lain adalah informasi mengenai data-data yang dibutuhkan untuk pengajuan sertifikasi dosen, perhitungan beban kerja dosen, pengajuan jabatan akademik dan fungsional dosen.

\section{Portofolio Pengajuan Sertifikasi Dosen}

Portofolio Dosen Yang di Sertifikasi (DYS) harus menyusun Curicullum Vitae (CV) yang terdiri atas riwayat pendidikan, riwayat pengajaran, riwayat pelatihan profesional, produk bahan ajar, riwayat penelitian, riwayat pengabdian, riwayat dan publikasi karya ilmiah, pertemuan ilmiah, peran di bidang kemahasiswaan, dan tanda prestasi/penghargaan. Template pengisian portofolio untuk pengajuan sertifikasi dosen berdasarkan Lampiran Deskripsi Diri Curriculum Vitae pada Buku Pedoman Sertifikasi Pendidik Bagi Dosen 2010.

\section{Portofolio Pengajuan Jabatan Fungsional Dosen}

Template pengisian portofolio untuk pengajuan jabatan fungsional dosen berdasarkan Surat Pernyataan Bidang A,B,C, dan D terdapat pada Buku Pedoman Operasional Penilaian Angka Kredit Kenaikan Pangkat/Jabatan Akademik Dosen Tahun 2014.

Komponen penilaian dalam jabatan akademik dosen terdiri dari (i) unsur utama yang meliputi: pendidikan (meliputi pendidikan sekolah dan pelaksanaan pendidikan (pengajaran), penelitian (meliputi pelaksanaan penelitian dan menghasilkan karya ilmiah sains/teknologi/seni/sastra), dan pengabdian kepada masyarakat dan (ii) unsur penunjang yang merupakan kegiatan pendukung pelaksanaan tugas pokok dosen. Jumlah angka kredit kumulatif minimal yang harus dipenuhi oleh setiap dosen untuk dapat diangkat dalam jabatan akademik paling sedikit dibutuhkan angka kredit 90\% (sembilan puluh persen) dari unsur utama tidak termasuk pendidikan sekolah yang memperoleh ijazah/gelar dan Pendidikan dan Pelatihan (Diklat) Prajabatan.

\section{Portofolio Evaluasi Beban Kerja Dosen}

Template pengisian portofolio untuk pengajuan jabatan fungsional dosen berdasarkan Lampiran I 
Format F1 Laporan beban Kerja Dosen Semester II Tahun 20017/2008.

\section{Identifikasi Kebutuhan Fungsional}

Dari analisis sistem awal diperoleh kebutuhan sistem untuk aplikasi portofolio dosen, yaitu fungsifungsi sistem, output/keluaran/form sistem, dan input sistem. Kebutuhan Fungsional adalah kebutuhan yang harus dipenuhi agar suatu sistem dapat berjalan atau dapat dikatakan kebutuhan tambahan yang memiliki input, proses dan output. Aplikasi portofolio dosen yang dibuat dirancang untuk memenuhi fungsi sebagai berikut: (a) Aplikasi harus dapat digunakan untuk mengelola data kegiatan tridharma perguruan tinggi yang dilakukan oleh dosen, seperti menyimpan, memperbaharui, menghapus, dan mencari data kegiatan tridharma yang dilakukan oleh dosen, meliputi data identitas diri, riwayat pendidikan, pengajaran, pembimbingan mahasiswa, penguji mahasiswa, publikasi, penelitian, produk bahan ajar, seminar/workshop, pengabdian kepada masyarakat, pengelolaan institusi, kemahasiswaan, penghargaan, organisasi profesi/ilmiah, dan lain-lain sesuai dengan kriteria yang dibutuhkan; dan (b) Aplikasi harus dapat digunakan untuk menghasilkan laporan data kegiatan tridharma yang dilakukan dosen yang mendukung proses sertifikasi dosen, mendukung proses pengajuan dan kenaikan jabatan dosen, mendukung proses pelaporan beban kerja dosen, dan proses lainnya yang membutuhkan portofolio dosen seperti akreditasi jurusan, akreditasi fakultas, pengajuan proposal penelitian, pengabdian kepada masyarakat, dan lain-lain.

\section{Identifikasi Kebutuhan Non Fungsional}

Spesifikasi kebutuhan non fungsional meliputi kebutuhan perangkat keras dan kebutuhan perangkat lunak. Perangkat keras yang dibutuhkan untuk membangun aplikasi adalah seperangkat komputer dengan spesifikasi Processor Intel ${ }^{\circledR}$ CORETM $^{\mathrm{T}}$ i52450M, CPU @2.5 GHz, 4.0 GB RAM. Perangkat lunak yang dibutuhkan untuk membangun aplikasi adalah Microsoft Windows 7, aplikasi Notepad++ sebagai editor teks, MySQL sebagai software database, XAMPP server sebagai web server, software Microsoft Visio untuk membuat diagram alir (flowchart), pembuatan UML diagram.

\section{B. Perancangan Sistem Usulan}

Perancangan sistemusulan meliputiperancangan kerangka kerja, fungsional, antarmuka, dan basis data sistem usulan.

\section{Perancangan Kerangka Sistem Usulan}

Perancangan kerangka sistem usulan diGambarkan dengan flowchart. Aplikasi portofolio dirancang untuk mengelola data kegiatan tridharma perguruan tinggi yang dilakukan oleh dosen, seperti menyimpan, memperbaharui, menghapus, dan mencari data kegiatan tridharma yang dilakukan oleh dosen, meliputi data identitas diri, riwayat pendidikan, pengajaran, pembimbingan mahasiswa, penguji mahasiswa, publikasi, penelitian, produk bahan ajar, seminar/workshop, pengabdian kepada masyarakat, pengelolaan institusi, kemahasiswaan, penghargaan, organisasi profesi/ilmiah, dan lain-lain sesuai dengan kriteria yang dibutuhkan. Kerangka kerja dari sistem usulan untuk pembangunan database portofolio diGambarkan menggunakan flowchart.

Untuk dapat membangun database portofolio dosen, dosen dapat memilih beberapa kategori yaitu identitas diri, pendidikan, pengajaran, pembimbing, penguji, organisasi, penghargaan, penelitian, publikasi, bahan ajar, seminar, PKM, institusi, dan kemahasiswaan. Setelah menentukan kategori portofolio maka dosen dapat melakukan pengisian, perubahan, penghapusan, dan pencarian data untuk kategori tersebut. Sistem akan menyimpan data yang sudah dikelola oleh dosen dalam database portofolio dosen yaitu berupa table-tabel sesuai dengan kategorinya masing-masing.

Sistem juga digunakan untuk menghasilkan laporan data kegiatan tridharma yang dilakukan dosen yang mendukung proses sertifikasi dosen, mendukung proses pengajuan dan kenaikan jabatan dosen, mendukung proses pelaporan beban kerja dosen, dan proses lainnya yang membutuhkan portofolio dosen. Pada laporan data portofolio dosen, dosen memilih kategori data yang akan ditampilkan dan menentukan periode waktu yaitu tanggal mulai dan tanggal berakhir, kemudian sistem akan menampilkan data portofolio kepada dosen sesuai dengan kategori dan periode waktu yang sudah ditentukan.

\section{Perancangan Fungsional Sistem Usulan}

Use case diagram mengGambarkan fungsionalitas yang diharapkan dari sebuah sistem. Yang ditekankan adalah "apa" yang diperbuat sistem, dan bukan "bagaimana". Sebuah use case merepresentasikan sebuah interaksi antara actor dengan sistem.

\section{Perancangan Basis Data}

Pada tahap ini akan dirancang basis data yang nantinya digunakan untuk penyimpanan data 
portofolio dosen. Dalam perancangan basis data sistem usulan, peneliti memilih perancangan basis data secara konseptual dengan pemodelan Entity Relationship.

\section{Perancangan Antarmuka Sistem Usulan}

Pada tahap ini dilakukan perancangan antarmuka program yang dibuat dengan tujuan supaya pemakai mudah mengerti. Perancangan antarmuka sistem merupakan rancangan untuk memasukkan data dan laporan sebagai informasi yang dihasilkan dari pengolahan data. Perancangan input dan output juga merupakan acuan pembuat sistem dalam merancang dan membangun sistem. Ada 2 tahap yang ditempuh dalam merancang antamuka, yaitu:

a. Merancang antarmuka masukan. Antarmuka masukan merupakan halaman untuk memasukkan data. Halaman ini dibuat untuk membantu pengguna dalam memasukkan data kedalam basis data.

b. Merancang laporan. Langkah selanjutnya adalah merancang laporan-laporan yang dihasilkan yaitu laporan kegiatan tridharma perguruan tinggi yang dilakukan oleh dosen dalam periode waktu tertentu sesuai dengan kebutuhan dosen untuk penyusunan kenaikan jabatan fungsional dan akademik, sertifikasi dosen, pelaporan evaluasi beban kerja dosen, dan kebutuhan lainnya.

\section{Perancangan Antarmuka Form Sign In}

Form Sign In adalah form yang pertama sekali ditampilkan pada saat menggunakan aplikasi portofolio dosen. Sign In adalah menu untuk masuk kedalam aplikasi portofolio dosen. Apabila kode dosen dan password yang dimasukkan valid maka dosen akan berhasil masuk kedalam aplikasi yang sudah dibuat dan bisa menjalankan fungsi untuk membangun dan membuat portofolio.

\section{Perancangan Antarmuka Form Menu Utama}

Form Home adalah form yang ditampilkan setelah sign in berhasil pada saat menggunakan aplikasi portofolio dosen. Terdapat menu home, identitas diri, pendidikan, pengajaran, pembimbing, penguji, organisasi profesi/ilmiah, penghargaan, penelitian, publikasi, bahan ajar, seminar, pengabdian kepada masyarakat, pengelolaan institusi, buat portofolio, change password, dan sign out.

Menu identitas diri, pendidikan, pengajaran, pembimbing, penguji, organisasi profesi/ilmiah, penghargaan, penelitian, publikasi, bahan ajar, seminar, pengabdian kepada masyarakat, pengelolaan institusi digunakan untuk membangun atau mengisi data portofolio dosen. Menu buat portofolio digunakan untuk membuat portofolio berdasarkan data yang sudah tersimpan di database portofolio dosen. Menu change password dan menu sign out digunakan untuk mengelola akun user yaitu untuk merubah password dan keluar dari aplikasi.

\section{Perancangan Antarmuka Form Identitas Diri}

Form identitas diri dirancang untuk mengelola data identitas diri dosen. Data identitas diri dapat diubah dan disimpan. Data identitas diri meliputi data NIP/NIK, nama, jenis kelamin, tempat lahir, tanggal lahir, status perkawinan, agama, golongan/ pangkat, jabatan akademik, perguruan tinggi, email, dan alamat rumah.

\section{Perancangan Antarmuka Form Pendidikan}

Form pendidikan dirancang untuk mengelola data pendidikan dosen yang dapat ditambahkan, diubah, dicari, dan disimpan. Untuk setiap pendidikan yang pernah ditempuh oleh dosen, datanya meliputi program, tahun, perguruan tinggi, jurusan, scan ijasah dan transkrip dalam format pdf.

\section{Perancangan Antarmuka Form Pengajaran}

Form pengajaran adalah form yang dirancang untuk mengelola data pengajaran yang dilakukan oleh dosen. Data pengajaran dapat ditambahkan, diubah, dicari, dan disimpan. Data pengajaran meliputi mata kuliah, program, institusi, jurusan, program studi, semester, tahun akademik dan upload SK mengajar. Perancangan antarmuka form pengajaran dapat dilihat pada Gambar 2.

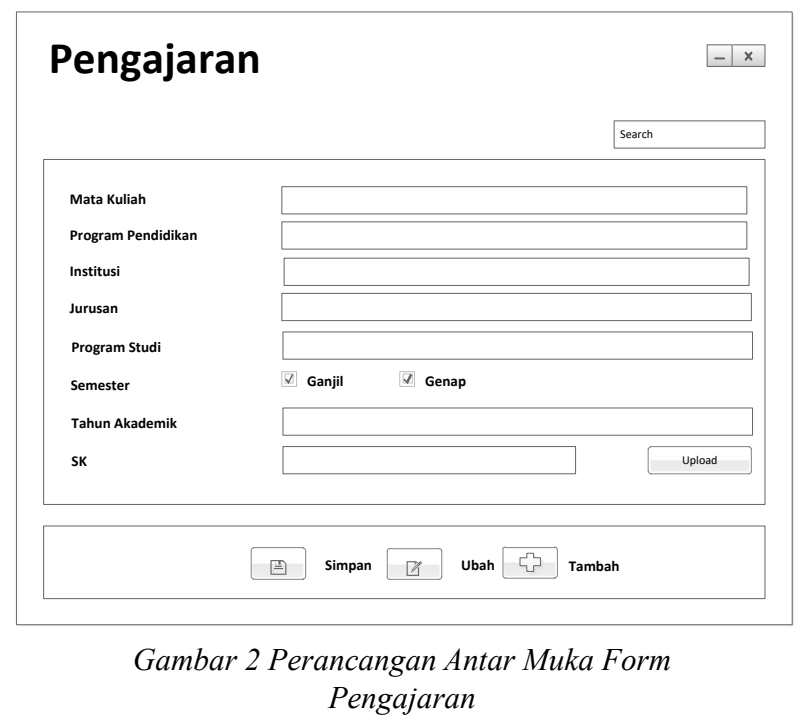

\section{Perancangan Antarmuka Form Penguji}

Form penguji adalah form yang dirancang untuk mengelola data penguji yang dilakukan oleh 
dosen terhadap mahasiswa. Data penguji dapat ditambahkan, diubah, dicari, dan disimpan. Data penguji meliputi nama mahasiswa, NIM, semester, tahun, program pendidikan, judul, peranan, dan upload SK sebagai penguji.

\section{Perancangan Antarmuka Form Organisasi Profesi/Ilmiah}

Form organisasi profesi/ilmiah adalah form yang dirancang untuk mengelola data organisasi profesi/ ilmiah yang diikuti oleh dosen. Data organisasi profesi/ilmiah dapat ditambahkan, diubah, dicari, dan disimpan. Data organisasi profesi/ilmiah meliputi tanggal mulai, tanggal berakhir, nama organisasi, jabatan dan upload bukti keikutsertaan organisasi profesi/ilmiah.

\section{Perancangan Antarmuka Form Penghargaan}

Form penghargaan adalah form yang dirancang untuk mengelola data penghargaan yang pernah diperoleh oleh dosen. Data penghargaan dapat ditambahkan, diubah, dicari, dan disimpan. Data penghargaan meliputi tanggal diberikan pengharaan, bentuk penghargaan, pemberi penghargaan, dan upload sertifikat atau bukti penghargaan.

\section{Perancangan Antarmuka Form Penelitian}

Form penelitian adalah form yang dirancang untuk mengelola data penelitian yang dilakukan oleh dosen. Data penelitian dapat ditambahkan, diubah, dicari, dan disimpan. Data meliputi tahun, judul, peranan, sumber dana, dan surat tugas penelitian.

\section{Perancangan Antarmuka Form Publikasi}

Form publikasi adalah form yang dirancang untuk mengelola data publikasi yang dilakukan oleh dosen. Data publikasi dapat ditambahkan, diubah, dicari, dan disimpan. Data publikasi meliputi tanggal, judul, jenis publikasi yaitu jurnal, prosiding, dan HAKI. Untuk data publikasi berupa jurnal terdapat data nama jurnal, penerbit, nomor, volume, ISSN, peranan, tahun, url, bukti penugasan, dan bukti kinerja. Untuk dapa publikasi berupa prosiding terdapat data nama seminar/konferensi, tempat, peranan, bukti penugasan, dan bukti kinerja. Untuk publikasi berupa HAKI terdapat data tempat, peranan, bukti penugasan, dan bukti kinerja. Perancangan antarmuka form publikasi seperti pada Gambar 5.

\section{Perancangan Antarmuka Form Bahan Ajar}

Form bahan ajar adalah form yang dirancang untuk mengelola data bahan ajar yang pernah dibuat oleh dosen. Data bahan ajar dapat ditambahkan, diubah, dicari, dan disimpan. Data bahan ajar meliputi mata kuliah, program, jenis, semester, tahun, judul, upload bukti penugasan dan bukti kinerja.

\section{Perancangan Antarmuka Form Seminar}

Form seminar adalah form yang dirancang untuk mengelola data seminar yang dilakukan oleh dosen. Data seminar dapat ditambahkan, diubah, dicari, dan disimpan. Data seminar meliputi tanggal, jenis, nama, penyelenggara, peranan, upload bukti penugasan dan bukti kinerja.

\section{Perancangan Antarmuka Form PKM}

Form seminar adalah form yang dirancang untuk mengelola data Pengabdian Kepada Masyarakat (PKM) yang dilakukan oleh dosen. Data PKM dapat ditambahkan, diubah, dicari, dan disimpan. Data PKM meliputi tanggal, nama, tempat, mitra, peranan, upload bukti penugasan dan bukti.

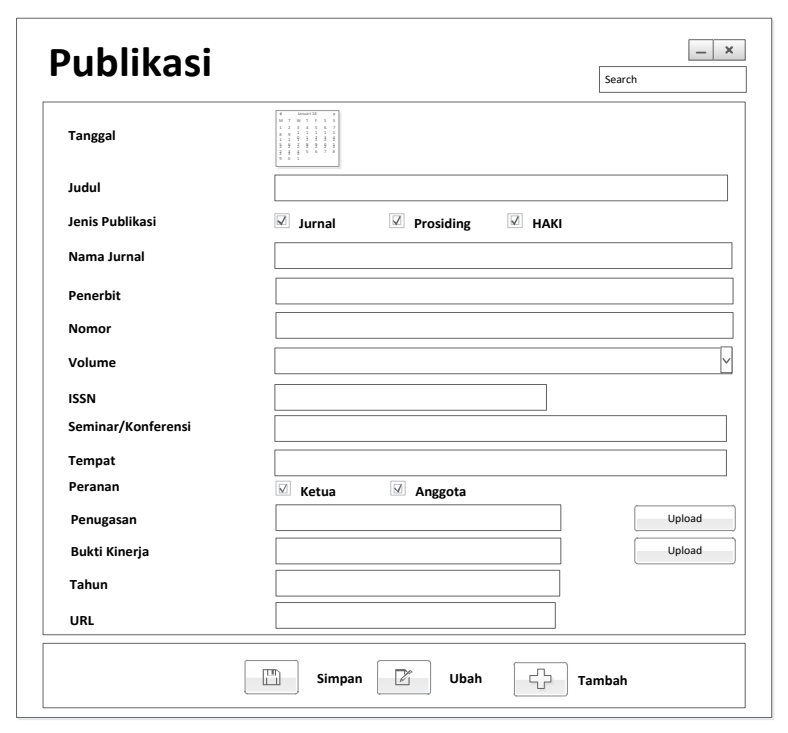

Gambar 3 Perancangan Antar Muka Form Publikasi

\section{Perancangan Antarmuka Form Pengelolaan Institusi}

Form pengelolaan institusi adalah form yang dirancang untuk mengelola data pengelolaan institusi yang dilakukan oleh dosen. Data pengelolaan institusi dapat ditambahkan, diubah, dicari, dan disimpan. Data pengelolaan institusi meliputi tanggal mulai, tanggal berakhir, peran/jabatan, institusi, dan upload SK pengelolaan institusi.

\section{Perancangan Antarmuka Form Buat Portofolio dan Form Output Laporan Portofolio Dosen}

Form buat portofolio adalah form yang dirancang untuk membuat laporan data portofolio 
dosen berdasarkan data portofolio yang sudah dibangun sebelumnya dan tersimpan dalam database portofolio. Pada menu buat portofolio, dosen dapat memilih kategori portofolio dan periode waktu yang diinginkan untuk dapat ditampilkan. Hasilnya adalah laporan data portofolio dosen sesuai dengan kategori dan dalam periode waktu yang telah ditentukan. Laporan yang dihasilkan adalah dalam format pdf yang bisa disimpan dan dicetak.

\section{Implementasi Sistem}

Bagian ini akan menjelaskan implementasi sistem yang terdiri dari implementasi basis data dan implementasi antarmuka aplikasi. Software yang digunakan dalam pembuatan aplikasi adalah XAMPP 3.2.2, pemrograman PHP 7.0. Sedangkan basis data yang digunakan adalah MySQL. Bisa dilihat pada Gambar 4 sampai dengan Gambar 8.

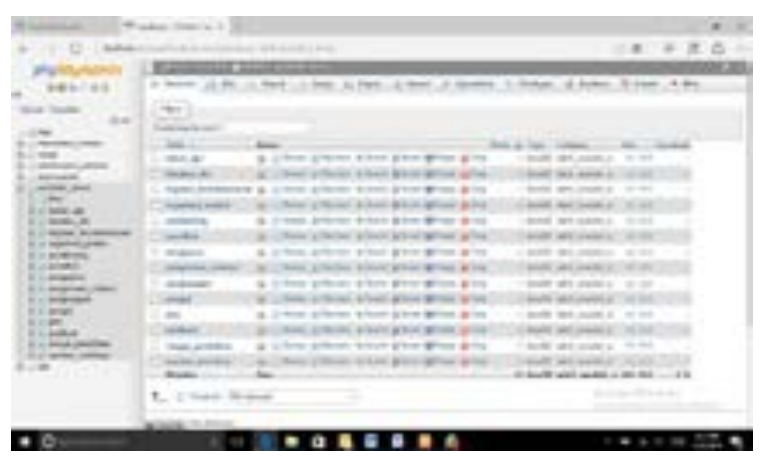

Gambar 4 Implementasi Basis Data Portofolio Dosen

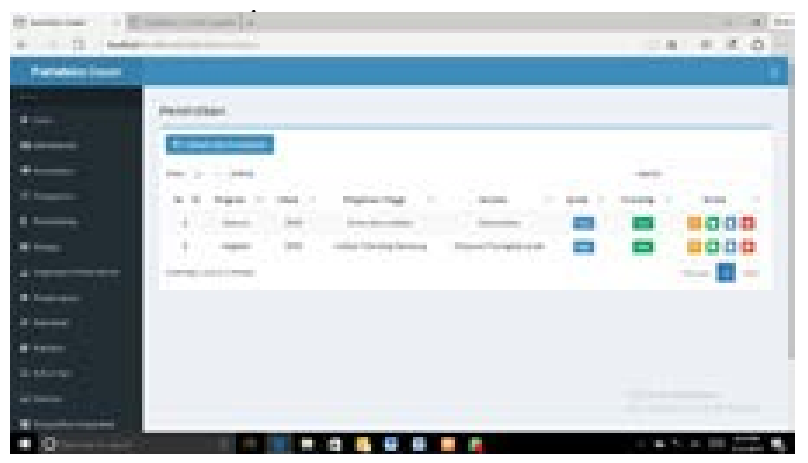

Gambar 5 Implementasi Antarmuka Form Pendidikan

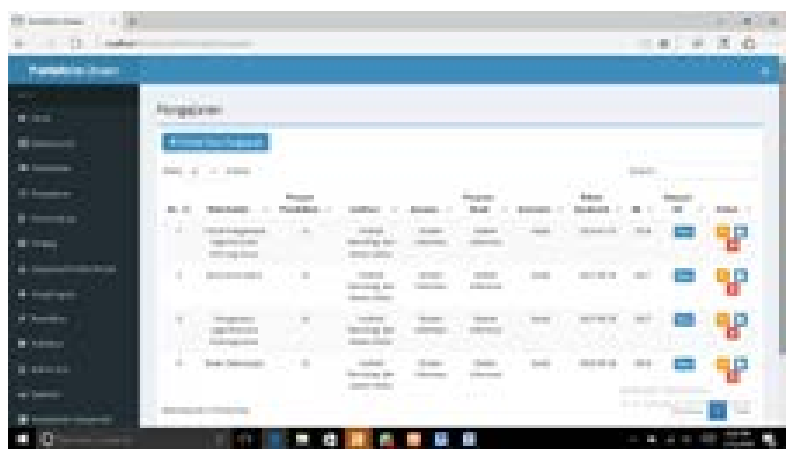

Gambar 6 Implementasi Antarmuka Form Pengajaran

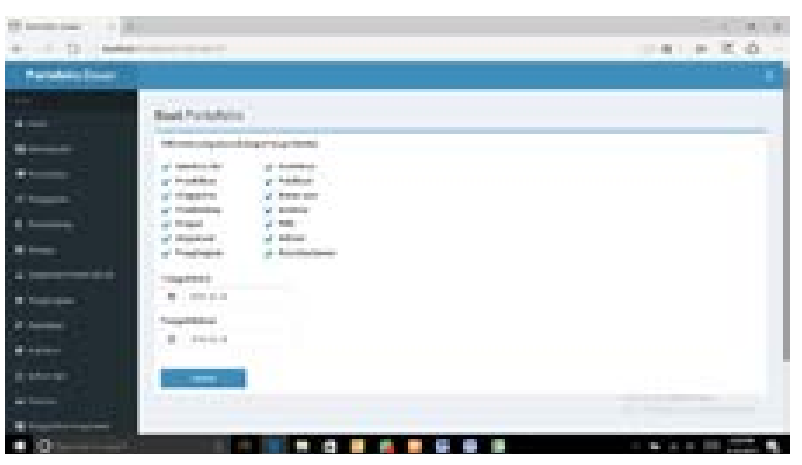

Gambar 7 Implementasi Antarmuka Pilih Kategori Portofolio Dosen

Psolsiuling

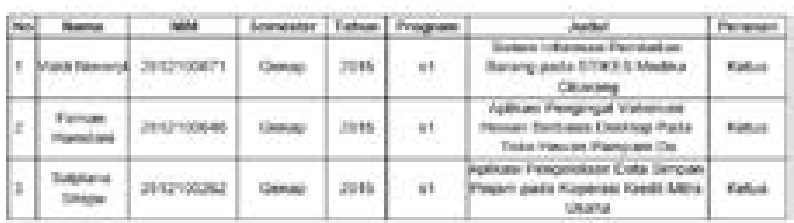

Simina:

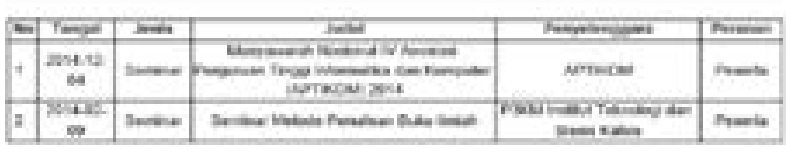

Peasuit

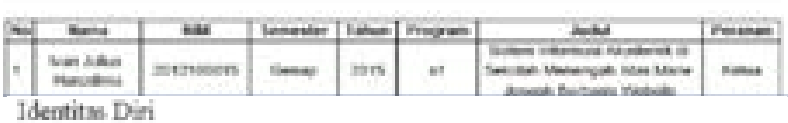

Identitas Diri

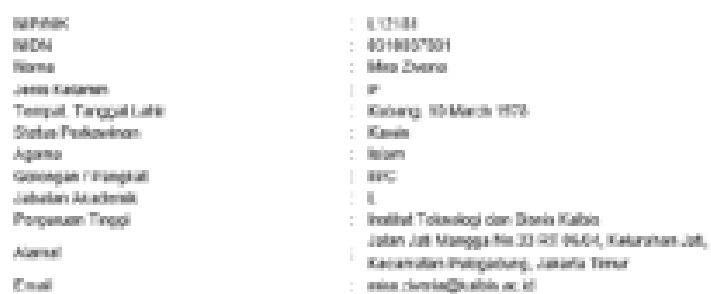

Penelititut

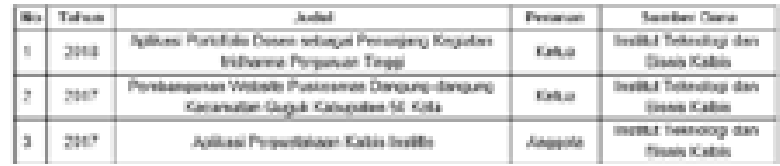

Gambar 8 Implementasi Layar Output Identitas Diri, Penelitian, Pembimbing, Seminar, dan Penguji

\section{Pengujian dan Evaluasi Sistem}

Pengujian aplikasi dilakukan dengan pengujian unit pada saat pengembangan dan pengujian sistem pada saat aplikasi selesai dikembangkan. Pengujian sistem yang dilakukan adalah pengujian spesifikasi. Pengujian performansi atau kinerja dilakukan bersamaan dengan tahapan evaluasi. Pengujian disajikan untuk sejumlah kasus yang dikembangkan untuk setiap faktor uji. Hasil pengujian dijelaskan 
melalui tabel yang memuat rencana kasus uji untuk faktor kebenaran dan tingkat layanan aplikasi. Pada tabel Rencana Kasus Uji Faktor Kebenaran dan Layanan Aplikasi terdiri dari kolom nomor, kasis uji, modul, dan kriteria uji. Dari 56 kriteria uji yang dilakukan, semuanya berjalan sesuai dengan yang direncanakan. Berdasarkan hasil pengujian yang telah dilakukan memberikan kesimpulan bahwa secara fungsional sistem sudah dapat menghasilkan output yang diharapkan. Dari hasil pengujian yang dilakukan dapat disimpulkan bahwa aplikasi portofolio dosen telah sesuai dengan apa yang diharapkan. Walaupun masih banyak kekurangan, tetapi secara fungsional sistem yang dibuat sudah sesuai dengan kebutuhan dosen untuk mengelola data pada sistem tridharma perguruan tinggi.

\section{SIMPULAN}

Bagian ini berisi kesimpulan yang diperoleh dari penelitian dan penyusunan laporan penelitian serta rekomendasi untuk penelitian selanjutnya. Kesimpulan yang dapat diambil dari penelitian aplikasi portofolio dosen untuk mengelola data kegiatan tridharma perguruan tinggi adalah: (1) Aplikasi portofolio dosen untuk mengelola data kegiatan tridharma perguruan tinggi dapat dikembangkan dengan metode pengembangan System Development Life Cycle; dan (2) Aplikasi portofolio dosen dapat digunakan untuk pengelolaan data identitas diri, pendidikan, pengajaran, bahan ajar, penelitian, publikasi, seminar/workshop, pengabdian kepada masyarakat, pembimbingan, penguji, pengelolaan institusi, kemahasiswaan, penghargaan, dan organisasi profesi/ilmiah.

\section{DAFTAR RUJUKAN}

[1] S. Wibawa, (2017, Maret 29). Tridharma Perguruan Tinggi (Pendidikan dan Pengabdian Kepada Masyarakat). [Online]. Available: http://itjen.ristekdikti.go.id/wpcontent/uploads/2017/02/TRIDHARMA-PT-ITJEN-1. pdf. Diakses tanggal 3 Januari 2018.

[2] Direktorat Jenderal Pendidikan Tinggi Departemen Pendidikan Nasional. Pedoman Beban Kerja Dosen dan Evaluasi Pelaksanaan Tri Dharma Perguruan Tinggi. Direktorat Jenderal Pendidikan Tinggi Departemen Pendidikan Nasional. 2010.

[3] Direktorat Jenderal Pendidikan Tinggi Kementerian Pendidikan dan Kebudayaan. Buku Pedoman Sertifikasi Pendidik Untuk Dosen (Serdos) Terintegrasi, Buku 3 Prosedur Operasional Baku Tata Laksana Serdos Terintegrasi. Direktorat Jenderal Pendidikan Tinggi Kementerian Pendidikan dan Kebudayaan. 2015.

[4] J. L. Whitten, et al., Metode Desain dan Analisis Sistem, Yogyakarta: ANDI dan McGraw Hill Education, 2006, hlm 80 .

[5] R. S. Pressman, et al., Software Engineering: A Practitioner's Approach Seventh Edition, New York, NY 100020: Mc Graw-Hill Companies, Inc, 2012, hlm $1-18$. 